\title{
Impact of tree species replacement on carbon stocks in a Mediterranean mountain area, NE Portugal
}

\author{
Felícia Fonseca $^{\mathrm{a}, *}$, Tomás de Figueiredo ${ }^{\mathrm{a}}$, Ângela Vilela ${ }^{\mathrm{a}}$, Renata Santos ${ }^{\mathrm{a}}$, Ana Luiza de Carvalho ${ }^{\mathrm{a}}$, \\ Eliane Almeida ${ }^{\mathrm{b}}$, Luís Nunes ${ }^{\mathrm{a}}$

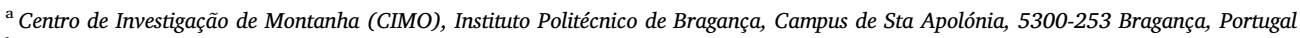 \\ ${ }^{\mathrm{b}}$ Departamento de Estruturas, Faculdade de Engenharia e Arquitetura, Universidade FUMEC, 30130-190 Belo Horizonte, Brazil
}

\section{A R T I C L E I N F O}

\section{Keywords:}

Forest systems

Biomass

Herbaceous vegetation

Forest floor

Mineral soil

\begin{abstract}
A B S T R A C T
Forest species replacement can influence significantly the amount of carbon stored in the several compartments that compose the terrestrial ecosystems (biomass, forest floor and mineral soil). This study intends to evaluate the influence of the replacement of the Quercus pyrenaica species (QP), which represents the climax vegetation of Serra da Nogueira, NE Portugal, by the Pseudotsuga menziesii (PM) and Pinus nigra (PN) plantations (fast-growing species). For this purpose, three plots of $314 \mathrm{~m}^{2}$ were established in each stand ( 9 plots in total) and the height and diameter at the breast height of all trees were measured, in order to characterize the stands and estimate the tree biomass. Herbaceous vegetation and forest floor were collected in areas of $0.49 \mathrm{~m}^{2}$ in 15 points under each tree species (5 per plot). At the same points, disturbed and undisturbed soil samples were collected at depths $0-5$, $5-10,10-15,15-20$ and $20-30 \mathrm{~cm}$. Thirty years after the climax vegetation replacement, carbon gains are observed in forest species biomass and forest floor $\left(1.3 \mathrm{Mg} \mathrm{C} \mathrm{ha}^{-1}\right.$ year $^{-1}$ in PN and $4.0 \mathrm{MgC} \mathrm{ha}^{-1}$ year $^{-1}$ in PM) and significant losses were recorded on soil carbon pool (about $2.2 \mathrm{MgC} \mathrm{ha}^{-1}$ year $^{-1}$ ). Total carbon accumulated is significantly higher in PM (331 $\left.\mathrm{MgC} \mathrm{ha}^{-1}\right)$ compared to PN (246 $\left.\mathrm{Mg} \mathrm{ha}^{-1}\right)$ and QP (273 Mg C ha-1), which present statistically similar values. Tree biomass and mineral soil constitute the major carbon pools.
\end{abstract}

\section{Introduction}

The increase in atmospheric carbon content, as expected considering actual trends, draws attention to the highly valuable role of forest ecosystems in the global carbon cycle (Eswaran et al., 1993; DíazPinés et al., 2011). Increasing carbon sequestration by increasing forest area, mainly through plantations of fast-growing species, has been suggested as an effective measure to mitigate atmospheric carbon concentration, which may contribute to the prevention of global warming (IPCC, 2001).

The majority of the native vegetation in Iberian Peninsula (Portugal and Spain) has been replaced by other forest species, particularly fastgrowing coniferous plantations. Although this substitution may have beneficial economic consequences, it is essential to understand environmental effects such as those in carbon sequestration for mitigation of greenhouse gases. The knowledge of the differences among species in what regards carbon sequestration and effects produced in each carbon pool of the ecosystem, should be a decision support tool when introducing new forest species and can be used strategically to reach environmental goals (Oostra et al., 2006; Schulp et al., 2008; Vallet et al., 2009; Herrero et al., 2016; Chen et al., 2016). Species replacement implies changes in carbon stocks in forest biomass and soils (Peltoniemi et al., 2004; Park, 2015), because tree species and litter quantity, quality and distribution in soil horizons have high influence in carbon storage (Lal, 2005; Oostra et al., 2006; Fonseca and Figueiredo, 2018). Decomposition rate of plant residues can be slower or faster, depending on their nature. In general, it is accepted that organic residues from coniferous species decompose more slowly than broadleaf species, for example, due to the presence of non-hydrolysable polyphenolic compounds in litter (Faulds and Williamson, 1999; Díaz-Pinés et al., 2011; Chen et al., 2016). On the other hand, fast-growing species would accumulate carbon more rapidly than slow-growing species, but the literature is controversial regarding the carbon stocks and distribution in the different compartments of the system (tree biomass, understory vegetation and soils), when the former species were replaced by the latter ones. Several studies shown that substitution leads to a global carbon loss (e.g. Schroth et al., 2002; Fonseca et al., 2004; Wang and Wang, 2007; Vallet et al., 2009; Ferré et al., 2014), while others studies reported carbon gains in the systems (e.g. Díaz-Pinés et al., 2011). This diversity of results may be linked to the biotic factors,

\footnotetext{
* Corresponding author.

E-mail address: ffonseca@ipb.pt (F. Fonseca).
} 
such as the vegetation, which influenced strongly the carbon stocks in forest biomass and soils (Vesterdal et al., 2013; Chen et al., 2016), and abiotic factors, as soil properties (Percival et al., 2000), time period considered after afforestation (Dick et al., 1998; Peichl and Arain, 2006), historical past of soil management (Post and Kwon, 2000; Ma et al., 2015) and site climate. Due to the great importance of soil in terrestrial ecosystems and the proportion of carbon stored there, slight changes resulting from disturbances, such as modifications in vegetation cover, fire and site preparation can influence the ecosystems sustainability in the long term (Percival et al., 2000; Lal, 2005; Park, 2015). Within the Kyoto Protocol and with the aim of generating carbon credits, some countries have been increasing the areas occupied by forests, improving management practices in existing areas or reorienting their production, an alternative for valuing of forests in relation to traditional logging (Cairns and Lasserre, 2004). Adequate species selection is a management option to increase carbon storage in forest systems (Vallet et al., 2009; Chen et al., 2016; Herrero et al., 2016).

The research hypothesis was that the forest species replacement affects the total carbon storage and its distribution in different compartments of the ecosystem. In this sense, the main objective of the present study was to quantify the impact of replacing a native broadleaf species (Quercus pyrenaica) by a fast-growing conifers plantations, Pseudotsuga menziesii and Pinus nigra, on carbon stocks in tree biomass, herbaceous vegetation biomass, forest floor and mineral soil, during three decades after stands establishment.

\section{Methods}

The study area was located in Serra da Nogueira, northeast of Portugal $\left(41^{\circ} 44^{\prime} \mathrm{N}\right.$ and $\left.6^{\circ} 52^{\prime} \mathrm{W}\right)$, in the range between 1000 and $1150 \mathrm{~m}$ altitude (Fig. 1). The annual average temperature is $12^{\circ} \mathrm{C}$ and annual average precipitation is $1100 \mathrm{~mm}$, concentrated from October to March (Agroconsultores and Coba, 1991). The native vegetation is Quercus pyrenaica (QP), which occupies about 6000 ha and represents the most extensive area of QP in Portugal. Over the last decades, some of the QP area has been replaced by fast-growing species, mainly Pseudotsuga menziesii and Pinus nigra, a process where wildfires had an important role. Soils are classified as Umbric Leptosols derived from maphic rocks (FAO/UNESCO, 1988; Agroconsultores and Coba, 1991), with high stoniness, normally subacid, moderate to high in organic matter content, low base exchange capacity, very low $\mathrm{P}$ and moderate to high $\mathrm{K}$ contents (Fonseca et al., 2004). Although the Quercus pyrenaica sampling area is about one kilometer away from the remaining sampling areas (Fig. 1), it is located in the same altitude range and on the same soil type and parent material, so it is to be expected similar soil and climatic conditions. The roads near the sampling areas (Fig. 1) are an integral part of the forest and are used mainly in stands management operations. Besides, a buffer strip was left in the border of each sampled plot (fifty meters width), where no sample was collected. Accordingly, the effects of both factors on the results were considered negligible.

To assess the impact of species replacement on carbon stocks in four compartments (tree biomass, herbaceous biomass, forest floor and mineral soil), three sampling areas were selected in adjacent locations with similar soil and climate conditions. The first area, covered by Quercus pyrenaica (QP), represents the original soil. The second area is in a 30 years old stand of Pseudotsuga menziesii (PM), and the third one, under Pinus nigra (PN), is also 30 years old. In each sampling area, three plots of $314 \mathrm{~m}^{2}$ were randomly defined, as $10 \mathrm{~m}$ radius circles (following common procedures in forest inventories). In each plot, trees were counted and height and diameter at the breast height (DBH) were measured of all trees, in order to characterize the stands and estimate the amount of above and belowground biomass of forest tree species. $\mathrm{PM}$ and PN species show differences in density (trees ha ${ }^{-1}$ ), height and diameter, aspects that translate into higher productivity for PM species (basal area and volume) (Table 1). QP stands result from natural regeneration, and trees are relatively thin and short, displaying the lowest

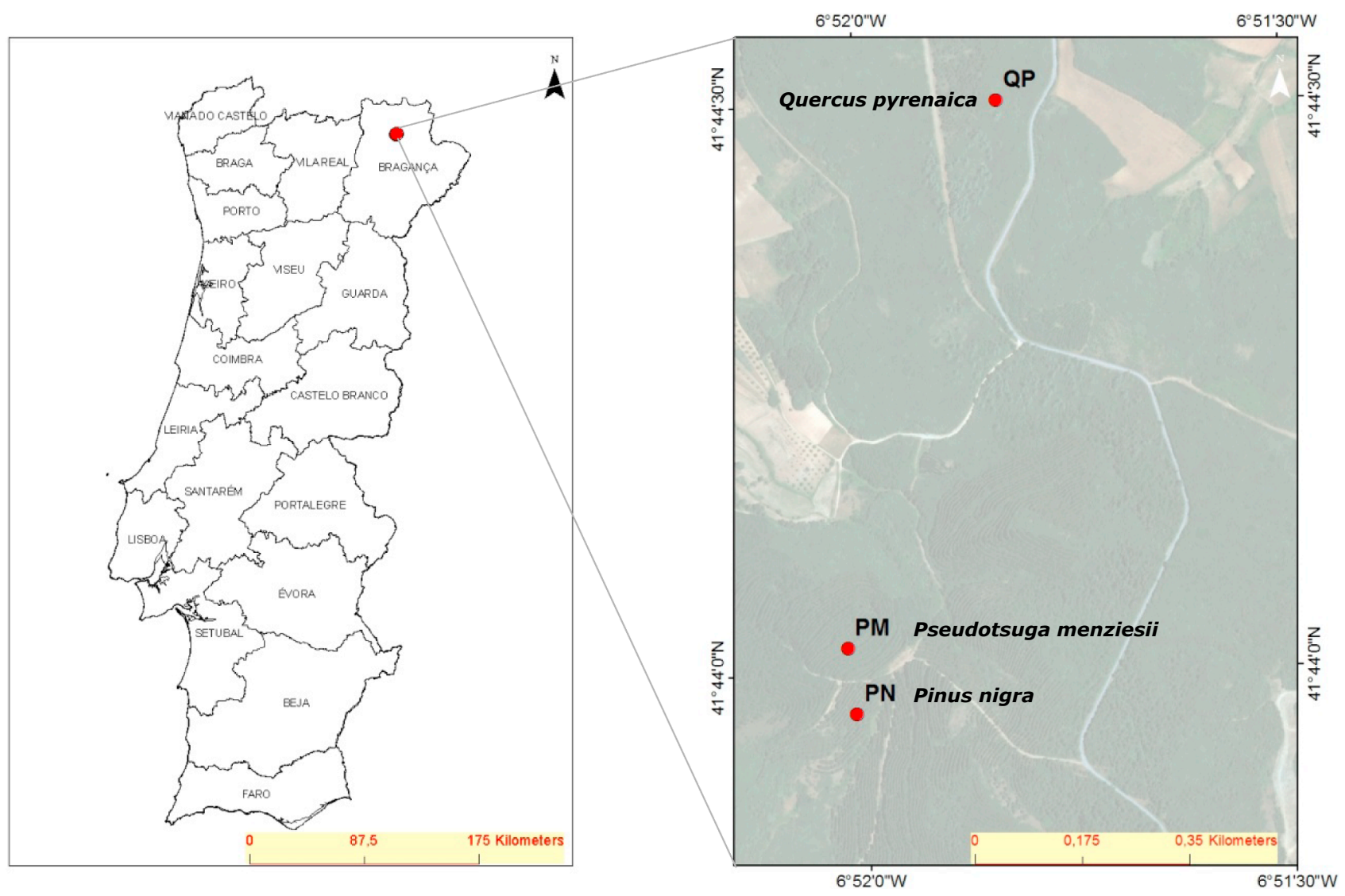

Fig. 1. Location of the study area in Serra da Nogueira, NE Portugal. 
Table 1

Silvicultural characteristics of the forest species Pseudotsuga menziesii (PM), Pinus nigra (PN) and Quercus pyrenaica (QP).

\begin{tabular}{llll}
\hline Parameters (units) & PM & PN & QP \\
\hline Density (trees ha ${ }^{-1}$ ) & 1189 & 967 & 2433 \\
Age (years) & 30 & 30 & - \\
Dominant height (m) & 23.3 & 16.1 & 10.4 \\
Average height (m) & 22.6 & 15.4 & 8.7 \\
Quadratic mean diameter (cm) & 25.7 & 23.8 & 12.3 \\
Basal area $\left(\mathrm{m}^{2} \mathrm{ha}^{-1}\right.$ ) & 62.1 & 43.4 & 28.7 \\
Volume $\left(\mathrm{m}^{3} \mathrm{ha}^{-1}\right)$ & 532.5 & 278.5 & 156.9 \\
Canopy cover (\%) & 98 & 85 & 80 \\
\hline
\end{tabular}

Table 2

Regression parameters ( $a$ and $b$ ) and standard error (SEE) used to estimate the above (ABG) and belowground (BGB) biomass (kg of dry matter) for Pseudotsuga menziesii (PM), Pinus nigra (PN) and Quercus pyrenaica (QP) forest species.

\begin{tabular}{lllll}
\hline \multirow{2}{*}{ Species } & \multirow{2}{*}{ Biomass } & \multicolumn{2}{l}{ Parameters } & \multirow{2}{*}{ SEE } \\
\cline { 3 - 4 } & & $\mathrm{a}$ & $\mathrm{b}$ & \\
\hline \multirow{2}{*}{ PM } & AGB & -2.21637 & 2.35162 & 0.073801 \\
& BGB & -2.46359 & 2.13727 & 0.229940 \\
PN & AGB & -2.7773 & 2.51564 & 0.134416 \\
& BGB & -3.76193 & 2.38784 & 0.179241 \\
QP & AGB & -2.59695 & 2.53453 & 0.247318 \\
& BGB & -2.4543 & 2.13346 & 0.242145 \\
\hline
\end{tabular}

productivity. Canopy cover was evaluated by direct observation in the field for PM (98\%), PN (85\%) and QP (80\%) stands (Table 1). Allometric relations with DBH as the independent variable (Table 2, Eq. (1)), developed by Montero et al. (2005), were used to estimate above and belowground biomass of tree species (PM, PN and QP):

$\mathrm{B}=\mathrm{CF} \times \mathrm{A} \times \mathrm{DHB}^{\mathrm{b}}$

where $\mathrm{B}$ is above or belowground biomass of forest species; CF is a correction factor; $\mathrm{CF}=e^{\left(\frac{S E E^{2}}{2}\right)}, \mathrm{SEE}$ is the standard error of estimation (see Table 2); $\mathrm{A}=\mathrm{e}^{\mathrm{a}}$; DHB is quadratic mean diameter.

Herbaceous aboveground biomass and forest floor were entirely collected in 5 areas of $70 \times 70 \mathrm{~cm}$ randomly established over each plot (following common procedures used to assess herbaceous vegetation and organic horizons in forest areas). Herbaceous root biomass was quantified based on a root-to-shoot ratio of $0.23 \pm 0.03$ obtained by Gonçalves et al. (2013) in a stand located approximately $15 \mathrm{~km}$ from the place where the current study took place. Forest floor material was separated according to morphological criteria into L-layer (Litter layer, composed by organic material recently fallen that is readily identifiable as to origin), F-layer (Fragmentation layer, comprised by organic material partly decomposed, but yet recognizable as to origin) and H-layer (Humus layer, comprised by well-decomposed organic material in which plant structures are generally not recognizable, containing considerable amount of mineral matter) (Wesemael, 1993; van Delft et al., 2006; Fonseca and Figueiredo, 2018). Herbaceous biomass and forest floor samples were dried at $65^{\circ} \mathrm{C}$ for $72 \mathrm{~h}$ to determine dry matter. In the same areas $(70 \times 70 \mathrm{~cm})$, disturbed and undisturbed soil cores were collected in the $0-5,5-10,10-1515-20$ and $20-30 \mathrm{~cm}$ of soil layers. Bulk density was determined in undisturbed samples, weighting ovendried soil (at $105^{\circ} \mathrm{C}$ ), collected in $100 \mathrm{~cm}^{3}$ cylinders. Soil samples were air dried and sieved with a $2 \mathrm{~mm}$ sieve, to determine the coarse elements content. All forest floor and mineral soil samples were analyzed for total C by dry combustion (ISO, 1995).

The carbon stored in tree biomass $\left(\mathrm{Mg} \mathrm{C} \mathrm{ha}{ }^{-1}\right)$ and herbaceous biomass ( $\mathrm{Mg} \mathrm{C} \mathrm{ha}{ }^{-1}$ ) was determined by multiplying the biomass values by 0.5 , average assumed as carbon concentration in dry matter, as accepted by several authors (e.g. Laclau, 2003; Petrokofsky et al., 2012;
Gonçalves et al., 2013). Forest floor mass values were converted to carbon $\left(\mathrm{Mg} \mathrm{C} \mathrm{ha}^{-1}\right)$ by multiplying these values by the carbon concentration in dry matter. Soil organic carbon contents $\left(\mathrm{C}_{\mathrm{SO}} ; \mathrm{Mg} \mathrm{C}\right.$ $\mathrm{ha}^{-1}$ ) were calculated by multiplying carbon concentration (Cc; $\mathrm{g}$ $\mathrm{kg}^{-1}$ ) by bulk density (BD; $\mathrm{g} \mathrm{cm}^{-3}$ ) and thickness $(\mathrm{z} ; \mathrm{cm}$ ) of the mineral soil layer with a correction for coarse elements content $\left(\mathrm{CE} ; \mathrm{v} \mathrm{v}^{-1}\right)$, using the following equation (Percival et al., 2000; Sil et al., 2017):

$\mathrm{C}_{\mathrm{SOC}}=\mathrm{z} \mathrm{Cc}(\mathrm{BD}-2.65 \mathrm{CE} / 100)$

The total carbon storage (TC) per unit area $\left(\mathrm{Mg} \mathrm{C} \mathrm{ha}^{-1}\right)$ was estimated by summing the mean amount of carbon in different pools:

$\mathrm{TC}=\mathrm{C}_{\mathrm{FS}}+\mathrm{C}_{\mathrm{HV}}+\mathrm{C}_{\mathrm{FF}}+\mathrm{C}_{\mathrm{SOC}}$

where $\mathrm{C}_{\mathrm{FS}}$ is carbon content in above and belowground forest species biomass; $\mathrm{C}_{\mathrm{HV}}$ is carbon content in above and belowground herbaceous vegetation biomass; $\mathrm{C}_{\mathrm{FF}}$ is carbon content in forest floor, $\mathrm{C}_{\mathrm{SOC}}$ is carbon content in mineral soil.

Statistical analysis comprised one-way ANOVA and multiple comparisons of averages (Tukey, 5\%) for assessing the effects of species replacement on carbon pools.

\section{Results and discussion}

\subsection{Carbon stocks in biomass of forest species}

The carbon stocks in the tree stratum biomass show clear differences after 30 years replacement of the native species (QP) by the PM and PN species (Fig. 2). Values for PM (with a mean of $196 \mathrm{Mg} \mathrm{C}^{-1}$ ) were significantly higher than those found for PN (114 Mg C ha-1) and QP $\left(80 \mathrm{Mg} \mathrm{C} \mathrm{ha}{ }^{-1}\right)$. Despite the statistically similar results obtained for PN and $\mathrm{QP}, \mathrm{PN}$ records an increase in aboveground tree biomass carbon pool as compared to QP. It should be noted that the PN is also considered a fast-growing species; nevertheless, the characteristics of this stand differ from those of the PM stand, the latter showing larger tree density (number of trees per hectare) and higher canopy cover (Table 1), both factors affecting carbon storage (Fonseca et al., 2004; Park, 2015). Fast-growing species, such as PM and PN, are more effective in carbon accumulation in biomass (Vallet et al., 2009; Gonçalves et al., 2013; Fonseca et al., 2014). According to Park (2015), modifications in vegetation cover, even when replacement involves species closely connected to each other, may produce important differences in total carbon stocks, as well as in the distribution of carbon across ecosystem compartments. The same author observed significant differences on tree carbon pool between Pinus resinosa and Pinus banksiana species. Identical results are reported by Chen et al. (2016) for the compared species (Pinus davidiana vs. Pinus sylvestris).

More than $70 \%$ of the carbon is stored in the aboveground biomass: $71 \%\left(57 \mathrm{Mg} \mathrm{Cha}^{-1}\right), 72 \%\left(141 \mathrm{Mg} \mathrm{Cha}^{-1}\right)$ and $80 \%\left(91 \mathrm{Mg} \mathrm{Cha}^{-1}\right)$ to

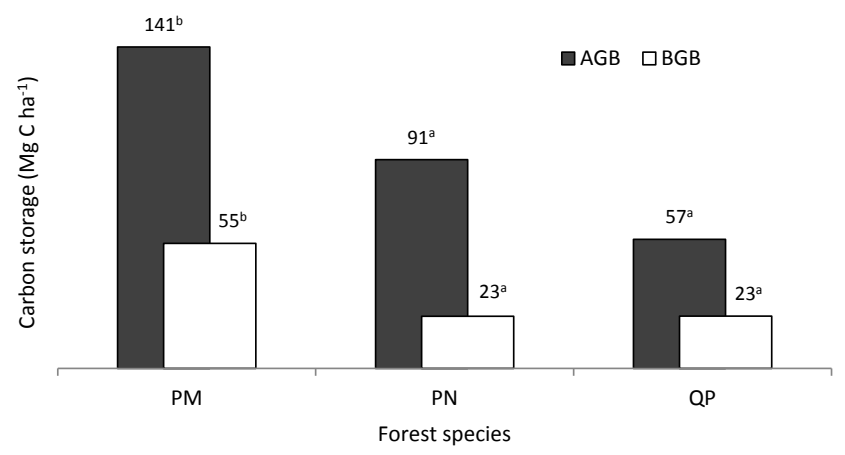

Fig. 2. Carbon storage in aboveground (AGB) and belowground (BGB) biomass of forest species Pseudotsuga menziesii (PM), Pinus nigra (PN) and Quercus pyrenaica (QP). Average values of each biomass component with the same letter are not significantly different $(\mathrm{p}>0.05)$. 
the QP, PM and PN species, respectively. Similar percentages were reported by Gonçalves et al. (2013) in a mixed stand of Pseudotsuga menziesii and Castanea sativa located in Northern Portugal. Carbon stocks in PM belowground biomass $\left(55 \mathrm{Mg} \mathrm{C} \mathrm{ha}^{-1}\right.$, equivalent to 1.8 $\mathrm{Mg} \mathrm{C} \mathrm{ha}{ }^{-1}$ year $^{-1}$ ) exceeded twice that found in the PN and QP stands (23 Mg C ha ${ }^{-1}$ for both species). It should be noted that, in temperate forest ecosystems, a greater accumulation of carbon in the aboveground biomass, as compared to the belowground, is commonly referred (e.g. Peichl and Arain, 2006; Vallet et al., 2009; Fonseca et al., 2014; Chen et al., 2016).

The carbon stored in tree biomass increased for both introduced species ( $\mathrm{PM}$ and $\mathrm{PN}$ ), reaching values that exceed those recorded for $\mathrm{QP}$ in $35 \mathrm{Mg} \mathrm{C} \mathrm{ha}{ }^{-1}$ or an average of $1.2 \mathrm{Mg} \mathrm{C} \mathrm{ha}^{-1}$ year $^{-1}$ in PN (all increment in aboveground biomass) and $116 \mathrm{Mg} \mathrm{C}^{-1}$ or an average of $3.9 \mathrm{Mg} \mathrm{C} \mathrm{ha}{ }^{-1}$ year $^{-1}$ in PM (84 Mg C ha ${ }^{-1}$ in aboveground biomass and $32 \mathrm{Mg} \mathrm{C}$ ha $^{-1}$ in belowground biomass). In contrast, Vallet et al. (2009) recorded carbon losses in tree biomass when the Quercus petraea (117 Mg C ha ${ }^{-1}$ ) was replaced by Pinus nigra (67 Mg C ha-1). It seems that, the carbon storage in tree biomass is controlled by species-specific development patterns.

\subsection{Carbon stocks in biomass of herbaceous vegetation}

Carbon storage in above and belowground biomass of herbaceous vegetation is not relevant (Fig. 3). In PN and QP species, herbaceous vegetation is scarce and dispersed owing to the presence of forest floor layers, which hindered their growth. Identical observations are reported by Gonçalves et al. (2013). In PM species, the presence of herbaceous vegetation was not observed since the high canopy cover of this species (Table 1), prevents sunlight reaching stand's ground surface. Park (2015) emphasize that the higher canopy cover in Pinus resinosa stands contributed to a low carbon stored in herbs and short shrubs understorey, accounting for less than $2 \%$ of the total carbon stored. The same author also noted that herb carbon decreased linearly with age while litter carbon increased linearly with age, which corroborates the observations recorded in the present study. Vallet et al. (2009) ignored the contributions of the herbaceous stratum in carbon stocks since this compartment represents roughly 4\% in French forests.

As mentioned, the contribution of carbon stocks in herbaceous vegetation to the total carbon stored is almost negligible (0, 0.2 and $0.3 \%$ for the PM, PN and QP species, respectively), adding in the system $0.48 \mathrm{Mg} \mathrm{C} \mathrm{ha}{ }^{-1}$ in PN and $0.84 \mathrm{Mg} \mathrm{C} \mathrm{ha}{ }^{-1}$ in QP. According to Gonçalves et al. (2013), the growth of herbaceous vegetation can be conditioned by the tree species that, over time, give rise to an organic horizon formed by litterfall and other parts of the trees, which, in turn, prevents understory vegetation development. Despite the reduced contribution of herbaceous vegetation to global carbon storage, the development of annual and perennial herbaceous plant communities

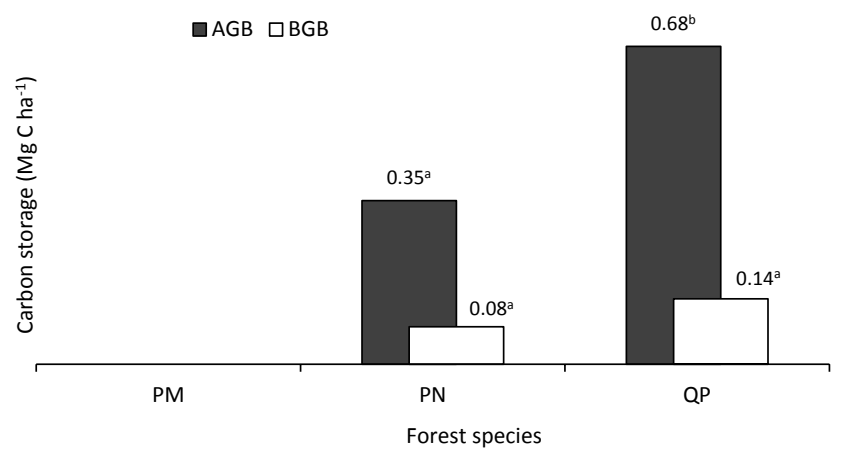

Fig. 3. Carbon storage in aboveground (AGB) and belowground (BGB) biomass in herbaceous vegetation. Average values of each biomass component with the same letter are not significantly different $(p>0.05)$. played an important role in the system productivity, and their rapid growth and death provided a significant source of organic carbon and nutrients to the soil (Mun and Whitford, 1998; Nicolini and Topp, 2005).

\subsection{Carbon stocks in the forest floor}

The forest floor dry matter accumulated on the soil surface under the three species is significantly higher for PM $\left(31.8 \mathrm{Mg} \mathrm{ha}^{-1}\right)$ and PN (27.1 $\left.\mathrm{Mg} \mathrm{ha}^{-1}\right)$, compared to QP $\left(18.4 \mathrm{Mg} \mathrm{ha}^{-1}\right)$, when considering the $\mathrm{L}, \mathrm{F}$ and $\mathrm{H}$ organic layers together (Table 3 ). These differences can be related to the decomposition rate of organic residues input at soil surface (Vesterdal et al., 2008; Vallet et al., 2009; Kooch et al., 2017; Fonseca and Figueiredo, 2018). Actually, large quantities of weakly decomposed organic material were observed under PM and PN species (conifer species), whilst under QP (broadleaf species) the organic residues show a much more advanced decomposition stage and incorporation in mineral soil. Identical results were obtained by other authors (Trum et al., 2011; Bargali et al., 2015; Chen et al., 2016; Fonseca and Figueiredo, 2018). Although the PN stand presents lower density (trees ha ${ }^{-1}$ ) than the PM stand (see Table 1 ), the high pine cones production by the PN may explain the absence of statistically significant differences between the two species, which is in agreement with Martins et al. (2009).

For all the tree species studied, carbon concentration decrease from $\mathrm{L}$ to $\mathrm{H}$ layers, showing similar values in $\mathrm{L}$ layer and significantly higher in $\mathrm{F}$ and $\mathrm{H}$ layers in PN and QP species (Table 3). The decrease of carbon concentration can be associated with the humification degree and with the addition of mineral particles at these layers, mainly owing to the soil biological activity (Wardle, 1993; Martins et al., 2009; Fonseca and Figueiredo, 2018).

Carbon stocks in whole forest floor (L, F and $\mathrm{H}$ layers) were significantly higher under PM (11.1 $\mathrm{Mg} \mathrm{Cha}^{-1}$ ) and PN (13.1 $\mathrm{Mg} \mathrm{C}^{-1}$ ) than QP (8.2 $\mathrm{Mg} \mathrm{C} \mathrm{ha}^{-1}$ ) (Fig. 4), which corresponds to an additional accumulation of $97 \mathrm{~kg} \mathrm{ha}^{-1}$ year ${ }^{-1}$ and $163 \mathrm{~kg} \mathrm{ha}^{-1}$ year $^{-1}$ for PM and PN species, respectively, as compared with QP. These amounts of carbon were higher when compared to $5.4 \mathrm{Mg} \mathrm{C}$ ha ${ }^{-1}$ stored in the forest floor of a 30-year-old Pinus strobus plantation (Peichl and Arain, 2006). It is also observed that, as compared to PN, PM species presents lower C stocks in all organic layers. PM forest floor is richer in calcium and magnesium, which favours the decomposition rate (Fonseca et al., 2004; Martins et al., 2009). In a research work on the effects of several forest species on carbon storage in temperate region, Vesterdal et al. (2013) reported that conifers species (Picea, Tsuga and Larix) accumulated more carbon in the forest floor than Quercus spp. The L layer recorded a slight increase statistically not significant in the carbon storage, 3.7, 3.8 and $3.2 \mathrm{Mg} \mathrm{C}$ ha $^{-1}$ for the species PM, PN and QP,

Table 3

Forest floor layers (L, F and $\mathrm{H}$ ) carbon concentration and dry matter under Pseudotsuga menziesii (PM), Pinus nigra (PN) and Quercus pyrenaica (QP) forest species, expressed as mean and standard deviation. For each forest floor layer means with the same letter across rows are not significantly different (P > 0.05).

\begin{tabular}{|c|c|c|c|}
\hline \multirow{2}{*}{$\begin{array}{l}\text { Forest floor } \\
\text { Layers }\end{array}$} & \multicolumn{3}{|l|}{ Species } \\
\hline & $\mathrm{PM}$ & $\mathrm{PN}$ & QP \\
\hline \multicolumn{4}{|c|}{ Carbon concentration $\left(\mathrm{g} \mathrm{kg}^{-1}\right)$} \\
\hline $\mathrm{L}$ & $520.3 \pm 24.7^{\mathrm{a}}$ & $552.6 \pm 11.3^{\mathrm{a}}$ & $539.4 \pm 5.8^{\mathrm{a}}$ \\
\hline $\mathrm{F}$ & $426.7 \pm 38.7^{\mathrm{a}}$ & $524.0 \pm 41.5^{\mathrm{b}}$ & $500.2 \pm 38.0^{\mathrm{b}}$ \\
\hline $\mathrm{H}$ & $216.7 \pm 63.9^{\mathrm{a}}$ & $390.3 \pm 59.2^{\mathrm{b}}$ & $385.2 \pm 70.1^{\mathrm{b}}$ \\
\hline \multicolumn{4}{|c|}{ Dry matter $\left(M g h a^{-1}\right)$} \\
\hline $\mathrm{L}$ & $7.2 \pm 3.3^{\mathrm{a}}$ & $6.9 \pm 3.6^{\mathrm{a}}$ & $5.9 \pm 1.1^{\mathrm{a}}$ \\
\hline $\mathrm{F}$ & $9.5 \pm 2.9^{\mathrm{b}}$ & $8.5 \pm 6.0^{b}$ & $3.8 \pm 1.3^{\mathrm{a}}$ \\
\hline $\mathrm{H}$ & $15.1 \pm 5.5^{\mathrm{b}}$ & $11.7 \pm 5.6^{\mathrm{ab}}$ & $8.7 \pm 3.6^{\mathrm{a}}$ \\
\hline Total & $31.8^{\mathrm{b}}$ & $27.1^{\mathrm{b}}$ & $18.4^{\mathrm{a}}$ \\
\hline
\end{tabular}




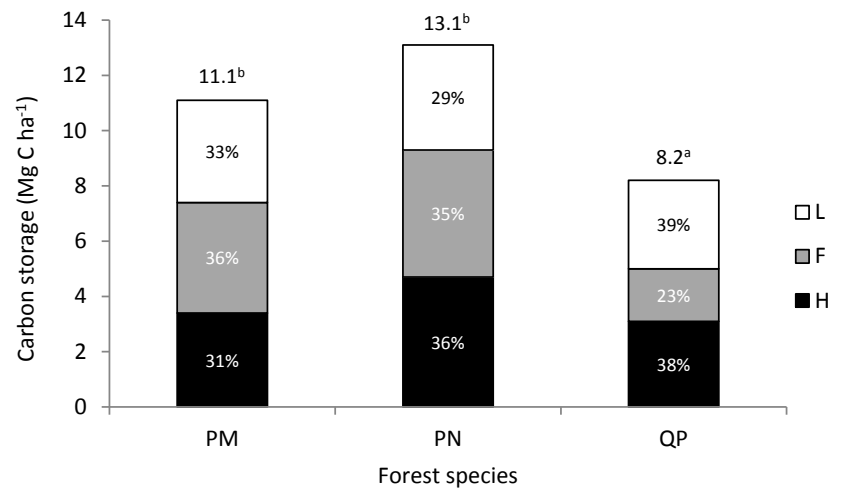

Fig. 4. Carbon storage in $\mathrm{L}, \mathrm{F}$ and $\mathrm{H}$ organic layers (forest floor). Average values with the same letter are not significantly different $(p>0.05)$.

respectively (Fig. 4). The $\mathrm{F}$ layer is the one with the highest carbon storage and the values are similar among PM $\left(4.0 \mathrm{Mg} \mathrm{C} \mathrm{ha}^{-1}\right)$ and PN (4.6 Mg C ha-1), and significantly higher than those found for QP species (1.9 Mg Cha ${ }^{-1}$ ). Finally, the $\mathrm{H}$ layer shows some discrepancies among the three species but without significant differences. A similar pattern of carbon distribution in L, F and $\mathrm{H}$ layers was obtained by Fonseca and Figueiredo (2018) when comparing conifers species (Pinus pinaster, Pinus nigra and Pseudotsuga menziesii) vs. a broadleaf species (Castanea sativa).

\subsection{Carbon stocks in the mineral soil}

The introduction of PM and PN species replacing QP (climax vegetation) reduced significantly the carbon concentration in all soil layers (Table 4). Although, PM species presents higher carbon concentration than PN species, both do not differ significantly from PN. The significant differences found between the introduced conifer (PM and $\mathrm{PN}$ ) and the native broadleaf (QP) species are seemingly due, at first, to soil disturbances when conifers stand was installed (PM and PN), which favoured soil organic matter mineralization (Schulp et al., 2008; Gonçalves et al., 2013; Ma et al., 2015). Conversely, broadleaf species (QP) store carbon in more stable form (Vesterdal et al., 2013).

Table 4

Soil carbon concentration $\left(\mathrm{g} \mathrm{C} \mathrm{kg}^{-1}\right)$, soil bulk density $\left(\mathrm{g} \mathrm{cm}^{-3}\right)$ and coarse fragments under forest species Pseudotsuga menziesii (PM), Pinus nigra (PN) and Quercus pyrenaica (QP), expressed as mean and standard deviation. For each soil layer means with the same letter across rows are not significantly different $(\mathrm{P}>0.05)$.

\begin{tabular}{|c|c|c|c|}
\hline \multirow[t]{2}{*}{ Depth (cm) } & \multicolumn{3}{|l|}{ Species } \\
\hline & PM & PN & QP \\
\hline \multicolumn{4}{|c|}{ SOC concentration $\left(g \mathrm{~kg}^{-1}\right)$} \\
\hline $0-5$ & $58.7 \pm 13.9^{\mathrm{a}}$ & $52.4 \pm 10.2^{\mathrm{a}}$ & $100.0 \pm 23.1^{\mathrm{b}}$ \\
\hline $5-10$ & $55.4 \pm 10.6^{\mathrm{a}}$ & $50.9 \pm 9.6^{\mathrm{a}}$ & $80.4 \pm 7.6^{b}$ \\
\hline $10-15$ & $54.5 \pm 17.6^{\mathrm{a}}$ & $45.4 \pm 5.3^{\mathrm{a}}$ & $74.7 \pm 8.0^{\mathrm{b}}$ \\
\hline $15-20$ & $48.4 \pm 12.0^{\mathrm{a}}$ & $44.3 \pm 5.3^{\mathrm{a}}$ & $66.9 \pm 7.4^{b}$ \\
\hline $20-30$ & $44.5 \pm 12.0^{\mathrm{a}}$ & $40.4 \pm 8.5^{\mathrm{a}}$ & $60.9 \pm 10.3^{\mathrm{b}}$ \\
\hline \multicolumn{4}{|c|}{ Bulk density $\left(\mathrm{g} \mathrm{cm}^{-3}\right)$} \\
\hline $0-5$ & $1.02 \pm 0.12^{\mathrm{a}}$ & $1.01 \pm 0.13^{\mathrm{a}}$ & $0.84 \pm 0.13^{\mathrm{b}}$ \\
\hline $5-10$ & $1.11 \pm 0.16^{\mathrm{a}}$ & $1.18 \pm 0.15^{\mathrm{a}}$ & $0.90 \pm 0.07^{\mathrm{b}}$ \\
\hline $10-20$ & $1.18 \pm 0.21^{\mathrm{a}}$ & $1.19 \pm 0.15^{\mathrm{a}}$ & $0.94 \pm 0.09^{\mathrm{b}}$ \\
\hline $15-20$ & $1.24 \pm 0.19^{\mathrm{a}}$ & $1.23 \pm 0.19^{\mathrm{a}}$ & $1.03 \pm 0.08^{\mathrm{b}}$ \\
\hline $20-30$ & $1.37 \pm 0.13^{\mathrm{a}}$ & $1.25 \pm 0.16^{\mathrm{a}}$ & $1.08 \pm 0.07^{\mathrm{b}}$ \\
\hline \multicolumn{4}{|c|}{ Coarse fragments (\%) } \\
\hline $0-5$ & $40.1 \pm 11.4^{\mathrm{a}}$ & $48.1 \pm 8.5^{\mathrm{b}}$ & $37.2 \pm 10.0^{\mathrm{a}}$ \\
\hline $5-10$ & $44.3 \pm 14.3^{\mathrm{b}}$ & $44.5 \pm 5.6^{b}$ & $32.0 \pm 12.4^{\mathrm{a}}$ \\
\hline $10-20$ & $48.7 \pm 16.5^{\mathrm{b}}$ & $42.5 \pm 7.6^{b}$ & $25.5 \pm 11.7^{\mathrm{a}}$ \\
\hline $15-20$ & $51.4 \pm 12.3^{\mathrm{b}}$ & $43.3 \pm 7.2^{\mathrm{b}}$ & $26.7 \pm 15.1^{\mathrm{a}}$ \\
\hline $20-30$ & $53.7 \pm 15.2^{\mathrm{b}}$ & $46.3 \pm 7.3^{b}$ & $25.3 \pm 5.5^{\mathrm{a}}$ \\
\hline
\end{tabular}

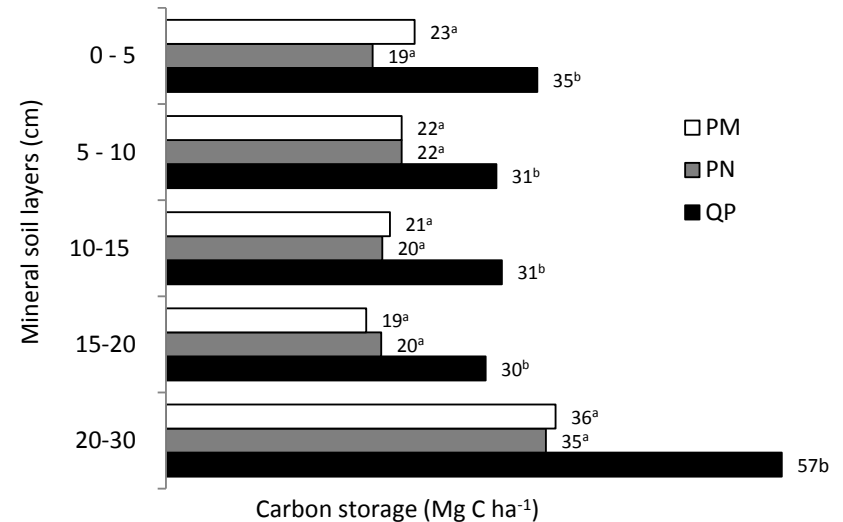

Fig. 5. Carbon storage in mineral soil layers of forest species Pseudotsuga menziesii (PM), Pinus nigra (PN) and Quercus pyrenaica (QP). Average values of each soil layer with the same letter are not significantly different $(p>0.05)$.

Also, tree species composition controls the inputs and biochemical characteristics of soil organic carbon (Díaz-Pinés et al., 2011). The carbon concentration decreased with soil depth while bulk density increased (Table 4), following a common variation pattern. Soil coarse elements showed a variation pattern with depth different according to forest species, but always with values higher than $25 \%$ of soil total dry mass (Table 4). These high coarse elements contents are commonly found in soils of the Mediterranean basin, in general, and specifically for the study area regional context (Díaz-Pinés et al., 2011; Fonseca et al., 2012; de Figueiredo, 2012).

Fig. 5 presents carbon stocks in the mineral soil layers analysed. At all depths, soil carbon accumulation under PM and PN species is significantly lower than that under QP species, which can be justified by several effects as site preparation (Fonseca et al., 2014; Ferré et al., 2014), management practices (Zhang et al., 2016) and the nature of the litterfall produced by each tree species (Vesterdal et al., 2013; Cools et al., 2014; Zhang et al., 2016; Fonseca and Figueiredo, 2018). These factors may promote the breakdown of soil aggregates, affect soil biological activity and, consequently, the mineralization rate of organic residues in the forest floor and of soil organic matter (Gonçalves et al., 2013; Herrero et al., 2016; Fonseca and Figueiredo, 2018). In general, carbon storage displays a vertical gradient, tending to decrease with increasing mineral soil depth. As stressed before, total carbon stored in the soil compartment $(0-30 \mathrm{~cm})$ is significantly higher under QP $\left(184 \mathrm{Mg} \mathrm{C} \mathrm{ha}^{-1}\right)$ than under PM $\left(121 \mathrm{Mg} \mathrm{C} \mathrm{ha}^{-1}\right)$ or PN $(116 \mathrm{Mg} \mathrm{C}$ $\mathrm{ha}^{-1}$ ) (Fig. 5), meaning values 34\% (PM) and 36\% (PN) lower in the introduced than in the native species (QP). Similar results are presented by Ferré et al. (2014), showing an overall decrease on soil organic carbon stocks, roughly $40 \%$, after 37 years of Populus euramericana plantation in areas formerly covered by natural forest (Quercus spp.), in northern Italy. Also, according to Lal (2005) soils under natural forest, in general, have more soil organic carbon contents than those under managed forest plantations. Herrero et al. (2016), in a study carried out in northern Spain, observed similar carbon content in soils when comparing plantations of Pinus spp. with natural Quercus pyrenaica areas ( $53 \mathrm{Mg} \mathrm{C} \mathrm{ha}^{-1}$ vs. $60 \mathrm{Mg} \mathrm{C}^{-1}$ ), these values being, however, clearly lower than those found in the present study. In contrast, a work developed in Central Spain, shows that Pinus sylvestris soils stored almost the double of carbon than Quercus pyrenaica soils at their ecotone (Díaz-Pinés et al., 2011). Disturbances that may occur in the soil such as changing vegetation cover, fires and management practices, influence in a long term the ecosystems sustainability and their ability to provide ecosystem services, such as carbon storage (e.g. Lal, 2005; Fonseca et al., 2014; Ferré et al., 2014; Chen et al., 2016; Sil et al., 2017; Fonseca and Figueiredo, 2018). The highest loss was recorded in the surface layer $\left(0-5 \mathrm{~cm} ; 11-15 \mathrm{Mg} \mathrm{C} \mathrm{ha}^{-1}\right)$, which may be related to a faster process of organic matter mineralization and gas exchanges with 
the atmosphere (Fernández et al., 1993; Gonçalves et al., 2013). The losses observed in each layer in the PM and PN species are identical, ranging from $0.0 \mathrm{Mg} \mathrm{C} \mathrm{ha}{ }^{-1}(5-10 \mathrm{~cm})$ to $4.0 \mathrm{Mg} \mathrm{C} \mathrm{ha}^{-1}(0-5 \mathrm{~cm})$. Comparing the values obtained for the whole mineral soil $(0-30 \mathrm{~cm})$ under the introduced with those under native species, carbon losses observed were of $62.7 \mathrm{Mg} \mathrm{C}^{-1}$, equivalent to $2.1 \mathrm{MgC} \mathrm{ha}^{-1}$ year $^{-1}$, for PM and of $66.8 \mathrm{MgC} \mathrm{ha}^{-1}$, equivalent to $2.2 \mathrm{MgC} \mathrm{ha}^{-1}$ year $^{-1}$ for $\mathrm{PN}$. The difference between PM and PN being only $6 \%$. Lower results, yet with a similar trend $\left(1.5 \mathrm{Mg} \mathrm{C}\right.$ ha $^{-1}$ year $\left.^{-1}\right)$, were obtained by Ferré et al. (2014), when studying a natural forest that was replaced by Populus euramericana cultivation. Taking into account the results obtained and since the organic matter content is essential in the maintenance of soil properties and, hence, in the conservation of the entire ecosystem, species substitution may be contributing to temporary and long-term ecosystem degradation.

\subsection{Total carbon stocks in the system}

The total amount of carbon accumulated in the system ranged from $245.6 \mathrm{Mg} \mathrm{C} \mathrm{ha}{ }^{-1}$ (PN) to $272.6 \mathrm{Mg} \mathrm{C} \mathrm{ha}^{-1}$ (QP) and to $333.1 \mathrm{Mg} \mathrm{C}$ $\mathrm{ha}^{-1}$ (PM) (Fig. 6). Overall, total carbon stocks increased in PM (55.4 $\mathrm{Mg} \mathrm{Cha}^{-1}$, equivalent to $1.8 \mathrm{Mg} \mathrm{Cha}^{-1}$ year $^{-1}$ ) and decreased in PN (27.4C Mg ha ${ }^{-1}$ equivalent to $0.9 \mathrm{Mg} \mathrm{C} \mathrm{ha}^{-1}$ year $^{-1}$ ) (Fig. 7), yet not significantly differing from the native QP species. Total carbon stock is relatively higher than that found by Vallet et al. (2009) when Quercus petraea (221 Mg C ha ${ }^{-1}$ ) was replaced by Pinus nigra (175 Mg C $\mathrm{ha}^{-1}$ ) over a 60 years period in Central France. In the present study, mineral soil and tree biomass were the largest carbon pools for all species, but with different pattern of distribution for the native (QP) and for introduced species (PN and PM). In QP, mineral soil was the most important carbon stock compartment and in PM and PN carbon stored in tree biomass assumed a more relevant importance, mainly in PM species. Carbon stocks in introduced tree biomass showed a large increase after 30 years replacement of the native forest, since in QP it represents $29 \%\left(80 \mathrm{Mg} \mathrm{Cha}^{-1}\right)$ of the total, passing to $60 \%(196 \mathrm{Mg} \mathrm{C}$ $\mathrm{ha}^{-1}$ ) in PM and to $47 \%$ (114 $\mathrm{Mg} \mathrm{C} \mathrm{ha}^{-1}$ ) in PN. In the introduced species, carbon increases due tree biomass and forest floor contributions were sufficient to cover the losses in the soil down to $30 \mathrm{~cm}$ depth, reaching similar values (PN) and significantly higher (PM), when compared to the original situation (QP).

The contribution of carbon stocks in herbaceous vegetation is very low, less than $1 \mathrm{MgC} \mathrm{ha}^{-1}$, representing $0,0.18$ and $0.28 \%$ of the total carbon stored for PM, PN and QP species, respectively. Although not expressive, there were losses in the contribution of herbaceous

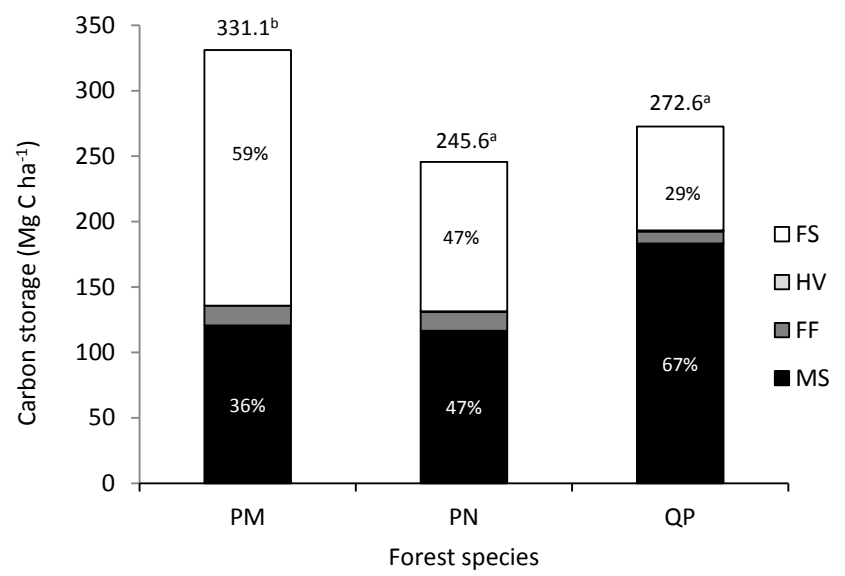

Fig. 6. Total carbon storage in the whole compartments of forest species Pseudotsuga menziesii (PM), Pinus nigra (PN) and Quercus pyrenaica (QP). Forest species (FS), herbaceous vegetation (HV), forest floor (FF) and mineral soil (MS). Average values of each tree species with the same letter are not significantly different $(\mathrm{p}>0.05)$. vegetation to total carbon storage after 30 years replacement of QP species by PM and PN species. Overall, the herbaceous vegetation stratum is often less developed in forest plantations than in natural forests (Peichl and Arain, 2006).

The increase in forest floor carbon storage from QP to introduced species ranged from $2.9 \mathrm{Mg} \mathrm{C}^{-1}$ (PM) to $4.9 \mathrm{Mg} \mathrm{Cha}^{-1}$ (PN). Their contribution to the total carbon stored in the system corresponded to 3.0, 4.8 and $2.7 \%$ for the species $\mathrm{PM}, \mathrm{PN}$ and QP, respectively. However, forest floor is an important component in the relationships soil-vegetation in forest systems, a crucial resource for nutrients cycling in forest soils (Smyth et al., 2015) and a fundamental part of the carbon biogeochemical cycle (Ordóñez et al., 2008; Zhang et al., 2016).

The soil is one of the main carbon pools in forest systems. Carbon accumulation in mineral soil under introduced conifers species (PM and $\mathrm{PN}$ ) ranged between 116 and $121 \mathrm{Mg} \mathrm{Cha}^{-1}$, which represents roughly two-thirds of that stored in QP $\left(184 \mathrm{Mg} \mathrm{C} \mathrm{ha}{ }^{-1}\right)$. Comparing the percent contribution of this compartment to total carbon storage in each tree species, considerable changes occurred after 30 years species replacement, since they fell down from $68 \%$ in QP to $37 \%$ in PM and $48 \%$ in $\mathrm{PN}$. Changes in land use directly affect gas exchange between terrestrial ecosystems and the atmosphere, with consequences for carbon storage (Watson, 2000; Park, 2015). Carbon stocks in forest ecosystems depends fundamentally on the complex interactions between climate, soils, tree species, management practices, quantity and quality of litter produced by the dominant species in the region concerned (Post and Kwon, 2000; Paul et al., 2002; Pregitzer and Euskirchen, 2004; Lal, 2005; Peichl and Arain, 2006; Vallet et al., 2009; Ma et al., 2015).

\section{Conclusions}

The results show that the mineral soil and tree biomass are the largest carbon pools; forest floor and herbaceous vegetation are not significant contributions to total carbon storage, with values lower than $5 \%$ and $1 \%$, respectively. Comparing the introduced species (PM and $\mathrm{PN}$ ) with the original situation (QP), after 30 years species replacement, forest floor (2.9 Mg C ha ${ }^{-1}$ for PM and $4.9 \mathrm{Mg} \mathrm{C} \mathrm{ha}^{-1}$ for PN) and tree biomass (116 Mg Cha ${ }^{-1}$ for PM and $35 \mathrm{Mg} \mathrm{Cha}^{-1}$ for PN) were carbon sinks, whilst mineral soil was a carbon source $\left(62.7 \mathrm{Mg} \mathrm{C}^{-1}\right.$ for PM and $66.7 \mathrm{Mg} \mathrm{C} \mathrm{ha}{ }^{-1}$ for PN). These findings highlight the effects of specific development patterns and of mechanized operations associated to PM and PN stands' installation. In this way, the research hypothesis was confirmed, since the total carbon stored and its distribution in the different system compartments was affected by the species replacement.

Vegetation cover changes, in relation to the total carbon stored in the system, was beneficial in case of PM species, presenting a gain of $16.9 \%$ as compared with the native species (QP), while PN species presented a loss of $10.1 \%$, even though, both (QP and PN) presented statistically similar results. The significant losses in mineral soil carbon compartment were rebalanced through the carbon gain in tree biomass and forest floor. In the current context whereby greenhouse gases effect, climate change and global warming have been emphasized; the replacement of native vegetation plays an important role in the dynamics of carbon in the atmosphere and in terrestrial ecosystems. Despite the increased productivity obtained with the introduced species (PM and PN, fast-growing species), it is necessary to focus attention on the impacts of species replacement in the mineral soil. Organic matter content is often one of the most influencing factors in physical, chemical and biological soil properties, and its reduction may have consequences on soil fertility, biodiversity and ecosystem resilience, and affecting sustainability. Consequently, the protection of soil organic matter assumes primary importance and it is essential to adopt strategies that allow soil organic matter conservation. Accordingly, the selection of tree species to be used in afforestation/reforestation programmes should take into account ecosystem services provided (e.g. carbon stocks) and ecosystem sustainability. 


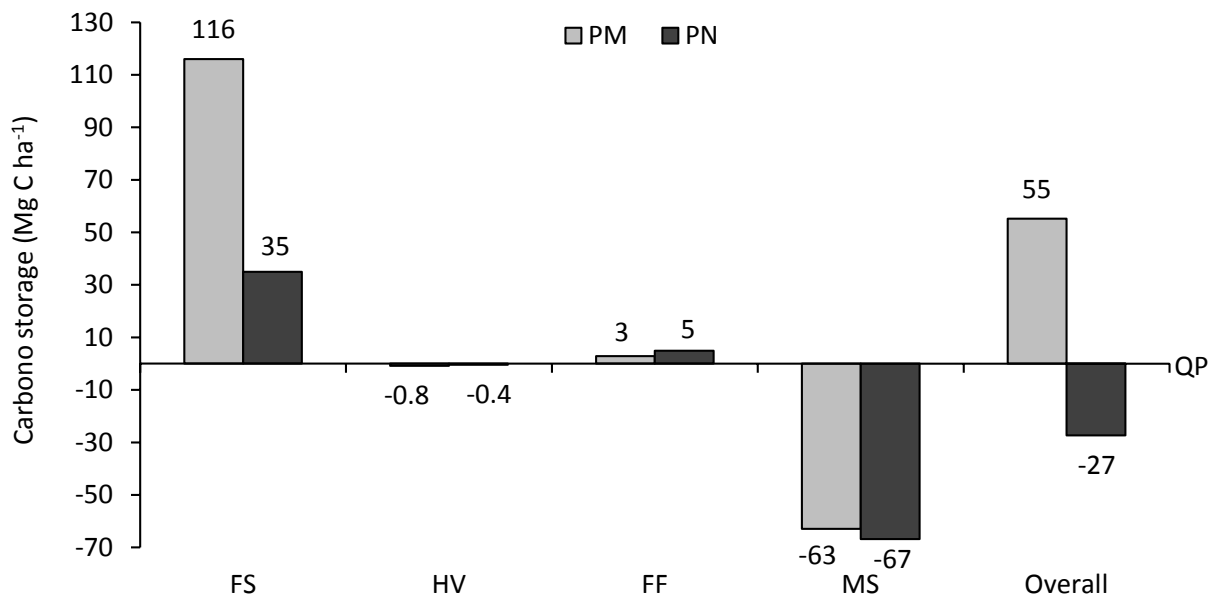

Fig. 7. Variation in carbon content in all compartments of the Pseudotsuga menziesii (PM) and Pinus nigra (PN) compared to original soil (QP). Forest species (FS), herbaceous vegetation (HV), forest floor (FF) and mineral soil layers.

\section{References}

Agroconsultores and Coba, 1991. Carta dos Solos do Nordeste de Portugal. UTAD, Vila Real.

Bargali, S.S., Shukla, K., Singh, L., Grosh, L., Lakhera, M.L., 2015. Leaf litter decomposition and nutrient dynamics in four tree species of dry deciduous forest. Tropical Ecol. 56 (2), 191-200.

Cairns, R.D., Lasserre, P., 2004. Reinforcing economic incentives for carbon credits for forests. For. Policy Econ. 6, 321-328.

Chen, G., Shen, H., Cao, J., Zhang, W., 2016. The influence of tree species on carbon storage in northern China. Forest. Chronicle 92 (3), 316-3021.

Cools, N., Vesterdal, L., De Vos, B., Vanguelova, E., Hansen, K., 2014. Tree species is the major factor explaining C: $\mathrm{N}$ ratios in European forest soils. For. Ecol. Manage. 311, 3-16.

Díaz-Pinés, E., Rubio, A., Miegroet, H.V., Montes, F., Benito, M., 2011. Does tree species composition control soil organic carbon pools in Mediterranean mountain forests? For. Ecol. Manage. 262, 1895-1904.

Dick, W.A., Blevins, R.L., Frye, W.W., Peters, S.E., Christenson, D.R., Pierce, F.J., Vitosh, M.L., 1998. Impacts of agricultural management practices on C sequestration in forest-derived soils of the eastern Corn Belt. Soil Tillage Res. 47, 235-244.

Eswaran, H., Berg, E.V.D., Reich, P., 1993. Organic carbon in soils of the world. Soil Sci. Soc. Am. J. 57, 192-194.

FAO/UNESCO, 1988. Soil Map of the World, Revised Legend, Amended 4th Draft. FAO, Roma.

Faulds, C.B., Williamson, G., 1999. The role of hydroxycinnamates in the plant cell wall. J. Sci. Food Agric. 79, 393-395.

Fernández, I.J., Son, Y., Kraske, C.R., Rustad, L.E., David, M.B., 1993. Soil carbon dioxide characteristics under different forest types and after harvest. Soil Sci. Soc. Am. J. 57, $1115-1121$.

Ferré, C., Comolli, R., Leip, A., Seufert, G., 2014. Forest conversion to poplar plantation in a Lombardy floodplain (Italy): effects on soil organic carbon stock. Biogeosciences 11, 6483-6493.

de Figueiredo, T., 2012. Pedregosidade dos Solos em Trás-os-Montes: importância relativa e distribuição espacial. Série Estudos 83, Instituto Politécnico de Bragança, Bragança.

Fonseca, F., Guerra, A., Nogueira, C., 2004. Efeito da substituição de espécies florestais nos horizontes orgânicos e características químicas do solo. Silva Lusitana 12 (2), 183-190.

Fonseca, F., Figueiredo, T., Ramos, M.A.B., 2012. Carbon storage in the Mediterranean upland shrub communities of Montesinho Natural Park, northeast of Portugal. Agroforestry Syst. 86, 463-475.

Fonseca, F., Figueiredo, T., Martins, A., 2014. Carbon storage as affected by different site preparation techniques two years after mixed forest stand installation. For. Syst. 23 (1), 84-92.

Fonseca, F., Figueiredo, T., 2018. Carbon and nitrogen in forest floor and mineral soil under four forest species in the Mediterranean region. Spanish J. Soil Sci. 8 (1) $42-56$.

Gonçalves, I., Fonseca, F., Figueiredo, T., 2013. Evolução temporal do carbono armazenado em povoamentos florestais jovens: efeito da intensidade de preparação do terreno. Silva Lusitana XXI ( ${ }^{\circ}$ Especial), pp. 111-125.

Herrero, C., Turrión, M.B., Pando, V., Bravo, F., 2016. Carbon content of forest floor and mineral soil in Mediterranean Pinus spp. and Oak stands in acid soils in Northern Spain. For. Syst. 25 (2), 13p.

IPCC, 2001. Climate change 2001: the scientific basis. Contribution of working group I to the third assessment report of the intergovernmental panel on climate change [Houghton, J.T., Y. Ding, D.J. Griggs, M. Noguer, P.J. van der Linden, X. Dai, K. Maskell, and C.A. Johnson (eds.)]. Cambridge University Press, Cambridge and New York, 881pp.

ISO, 1995. Soil quality - determination of organic and total carbon after dry combustion (elementary analysis). International Standard ISO 10694. International Organization for Standardization, Geneva (Switzerland).

Kooch, Y., Samadzadeh, B., Hosseini, S.M., 2017. The effects of broad-leaved tree species on litter quality and soil properties in a plain forest stand. Catena 150, 223-229.

Laclau, P., 2003. Biomass and carbon sequestration of ponderosa pine plantations and native cypress forests in northwest Patagonia. For. Ecol. Manage. 180, 317-333.

Lal, R., 2005. Forest soils and carbon sequestration. For. Ecol. Manage. 220 (1-3), $242-258$.

Ma, J., Bu, R., Liu, M., Chang, Y., Qin, Q., Hu, Y., 2015. Ecosystem carbon storage distribution between plant and soil in different forest types in Northeastern China. Ecol. Eng. 81, 353-362.

Martins, A., Azevedo, S., Raimundo, F., Carvalho, L., Madeira, M., 2009. Decomposição de folhada de quatro espécies florestais no Norte de Portugal: Taxa de decomposição e evolução da composição estrutural e do teor em nutrientes. Revista de Ciências Agrárias 32 (1), 223-237.

Montero, G., Ruiz-Peinado, R., Muñoz, M., 2005. Producción de biomasa y fijación de $\mathrm{CO}_{2}$ por los bosques españoles. España, Madrid.

Mun, H.T., Whitford, W.G., 1998. Changes in mass and chemistry of plant roots during long-term decomposition on a Chihuahuan Desert watershed. Biol. Fertility Soils 26, $16-22$.

Nicolini, F., Topp, W., 2005. Soil properties in plantations of sessile oak (Quercus petraea) and red oak (Quercus rubra) in reclaimed lignite open-cast mines of the Rhineland. Geoderma 129, 65-72.

Oostra, S., Majdi, H., Olsson, M., 2006. Impact of tree species on soil carbon stocks and soil acidity in southern Sweden. Scand. J. For. Res. 21, 364-371.

Ordóñez, J.A.B., de Jong, B.H.J., García-Oliva, F., Aviña, F.L., Pérez, J.V., Guerrero, G., Martínez, R., Masera, O., 2008. Carbon content in vegetation, litter and soil under 10 different land-use and land-cover classes in the Central Highlands of Michoacan, Mexico. For. Ecol. Manage. 255, 2074-2084.

Park, A., 2015. Carbon storage and stand conversion in a pine-dominated boreal forest landscape. For. Ecol. Manage. 240, 70-81.

Paul, K.I., Polglase, P.J., Nyakuengama, J.G., Khanna, P.K., 2002. Change in soil carbon following afforestation. For. Ecol. Manage. 168, 241-257.

Peichl, M., Arain, M.A., 2006. Above- and belowground ecosystem biomass and carbon pools in an age-sequence of temperate pine plantation forests. Agric. For. Meteorol. $140,51-63$.

Peltoniemi, M., Mäkipää, R., Liski, J., Tamminen, P., 2004. Changes in soil carbon stand age-an evaluation of a modeling method with empirical data. Global Change Biol. 10, 2078-2091.

Percival, H.J., Parfitt, R.L., Scott, N.A., 2000. Factors controlling soil carbon levels in New Zealand grasslands: Is clay content important? Sci. Soc. Am. J. 64, 1623-1630.

Petrokofsky, G., Kanamaru, H., Achard, F., Goetz, S., Joosten, H., Holmgren, P., Wattenbach, M., 2012. Comparison of methods for measuring and assessing carbon stocks and carbon stock changes in terrestrial carbon pools. How do the accuracy and precision of current methods compare? A systematic review protocol. Environ. Evid. 1 (6), 21p.

Post, W.M., Kwon, K.C., 2000. Soil carbon sequestration and land-use change: processes and potential. Global Change Biol. 6, 317-327.

Pregitzer, K., Euskirchen, E., 2004. Carbon cycling and storage in world forests: biome patterns related to forest age. Global Change Biol. 10, 2052-2077.

Schroth, G., D'Angelo, S.A., Teixeira, W.G., Haag, D., Lieberei, R., 2002. Conversion of secondary forest into agroforestry and monoculture plantations in Amazonia: consequences for biomass, litter and soil carbon stocks after 7 years. For. Ecol. Manage. $163,131-150$.

Schulp, C.J.E., Nabuurs, G.-J., Verburg, P.H., de Waal, R.W., 2008. Effect of tree species on carbon stocks in forest floor and mineral soil and implications for soil carbon inventories. For. Ecol. Manage. 256, 482-490.

Sil, A., Fonseca, F., Gonçalves, J., Honrado, J., Marta-Pedroso, C., Alonso, J., Ramos, M., Azevedo, J., 2017. Analysing carbon sequestration and storage dynamics in a changing mountain landscape in Portugal: insights for management and planning. Int. J. Biodiversity Sci., Ecosyst. Services Manage. 13 (2), 82-104. 
Smyth, C.E., Macey, D., Trofymow, J.A., 2015. Long-term litter decay in Canadian forests and the influence of soil microbial community and soil chemistry. Soil Biol. Biochem. 80, 251-259.

Trum, F., Titeux, H., Ranger, J., Delvaux, B., 2011. Influence of tree species on carbon and nitrogen transformation patterns in forest floor profiles. Ann. For. Sci. 68 (4), 837-847.

Vallet, P., Meredieu, C., Seynave, I., Bélouard, T., Dhôte, J.F., 2009. Species substitution for carbon storage: Sessile oak versus Corsican pine in France as a case study. For. Ecol. Manage. 257, 1314-1323.

van Delft, B., de Waal, R.W., Kemmers, R.H., Mekkink, P., Sevink, J., 2006. Field Guide Humus Forms: Description and Classification of Humus Forms for Ecological Applications. Wageningen, Alterra.

Vesterdal, L., Schmidt, I.K., Callesen, I., Nilsson, L.O., Gundersen, P., 2008. Carbon and nitrogen in forest floor and mineral soil under six common European tree species. For. Ecol. Manage. 255, 35-48.
Vesterdal, L., Clarke, N., Sigurdsson, B.D., Gundersen, P., 2013. Do tree species influence soil carbon stocks in temperate and boreal forests? For. Ecol. Manage. 309, 4-18.

Wang, Q.K., Wang, S.L., 2007. Soil organic matter under different forest types in Southern China. Geoderma 142, 349-356.

Wardle, D.A., 1993. Changes in the microbial biomass and metabolic quotient during leaf litter succession in some New Zealand forest and scrubland ecosystems. Funct. Ecol. 7, 346-355.

Watson, R.T., 2000. Land Use, Land-Use Change, and Forestry: A Special Report of the IPCC. Cambridge University Press, Cambridge.

Wesemael, B.V., 1993. Litter decomposition and nutrient distribution in humus profiles in some Mediterranean forests in southern Tuscany. For. Ecol. Manage. 57, 99-114.

Zhang, M., Yang, H., Xie, B., Sun, P., Li, J., Zou, J., Wang, Y., 2016. Changes of C and N stocks in the subtropical Dianchi lake watershed in southwest China due to LUCC. Eurasian J. Soil Sci. 5 (1), 17-23. 